\title{
Perceived Health, Physical Activity and Sport among the Elderly of Spain
}

\author{
Rafael Serrano-del-Rosal ${ }^{1}$, Lourdes Biedma-Velázquez ${ }^{1}$, David Moscoso-Sánchez ${ }^{2}$, \\ María Martín-Rodríguez ${ }^{3}$ \\ ${ }^{1}$ Institute for Advanced Social Studies, Spanish National Research Council (IESA-CSIC), Córdoba, Spain \\ ${ }^{2}$ Social Sciences Department, Pablo de Olavide University, Sevilla, Spain \\ ${ }^{3}$ Faculty of Physical Activity and Sport Sciences, Polytechnic University of Madrid, Madrid, Spain \\ Email: rserrano@iesa.csic.es
}

Received April $1^{\text {st }}, 2013$; revised May $2^{\text {nd }}, 2013$; accepted May $10^{\text {th }}, 2013$

Copyright (C) 2013 Rafael Serrano-del-Rosal et al. This is an open access article distributed under the Creative Commons Attribution License, which permits unrestricted use, distribution, and reproduction in any medium, provided the original work is properly cited.

\begin{abstract}
Purpose: It determines if participating in sports and/or physical activity influences perceived health among the elderly. Basic procedures: Data were drawn from a population subsample of subjects aged 65 - 79 years old that took part in a survey conducted in 2008 by the IESA-CSIC. A regression model was performed with perceived health status with the dependent variable and sociodemographic characteristics and physical activity as independent variables. Results: Physical activity is closely associated to perceived health, although sport has little influence on this relationship. Conclusions: Doing exercise or feeling that one is physically active makes the elderly feel better about their health status. However, this age group practises few sports and sport is not found to have an important or constant influence on self-perceived health status among the elderly.
\end{abstract}

Keywords: Perceived Health; Physical Activity; Sport; Elderly

\section{Introduction}

Much attention has been given in the specialised literature on physical activity, sport and health to the association between physical activity and health. While many authors have demonstrated this relationship from a physiological approach, others have focused on psychological, attitudinal or behavioural factors among others (Barrios, Borges, \& Cardoso, 2003).

All of these approaches coincide in acknowledging the beneficial effects of sport and physical activity on health at any age (USDH, 2008; Armstrong \& Morgan, 1998), with some studies focusing specifically on the benefits of exercise tailored to the elderly (Weineck, 2001).

As regards the issue of health and physical activity, it is important to bear in mind that the most highly developed western societies are characterised by two fundamental trends. On the one hand, processes that were once carried out by human beings by means of sheer physical strength and activity (transport, work, etc.) have now been mechanised and automated, thus giving rise to an important and relatively recent social phenomenon: sedentary life. On the other hand, life expectancy has increased to record levels (Fernández, Clúa, Báez, Ramírez, \& Prieto, 2000). These trends have led to population ageing; a process that is particularly marked in societies such as Spain where citizens aged 65 years or older account for 16.5 per cent of the population according to data from the Spanish Institute of Statistics (INE, 2008); a percentage that increases to nearly 19 per cent in the case of women, thus ranking Spain among the countries with the oldest population in the world. Contemporary western societies therefore face a two-fold challenge: an ageing population and sendentariness. Both of these factors affect people's health and are a matter of concern to public authorities responsible for analysing the social and economic costs of these social phenomena (Weineck, 2001). Sedentary lifestyle is believed to be the cause of $9-16$ per cent of all deaths occurring in developed western countries (Entrala, Iglesias, Veigas, \& De-Jesús, 2003) and held to be the underlying cause of death, disease and disability by the World Health Organization (WHO). According to WHO, sedentary lifestyle is among the ten leading risk factors of death and disability in the world as it is associated to cardiovascular disease, diabetes, high blood pressure, obesity, osteoporosis and depression, among other disorders (WHO, 1952). In recent decades, however, the concept of health has extended beyond a strictly biomedical definition of the term (absence of disease or infirmity). WHO, for example, defines health as a state of complete physical, mental and social well-being (WHO, 1952). Consequently, research into the effects of sedentary lifestyles on health and population ageing should not be measured strictly in terms of objective or biomedical indicators of health. In this line, perceived health status has been shown to be an excellent proxy of overall health as it reflects the multidimensionality of the concept of health as a state of overall well-being (Fernández-Ballesteros, 1992; Ware, 1987; Testa \& Simonson, 1996). Perceived health status has also been shown to be an excellent predictor of mortality and an even more comprehendsive and effective indicator than clinical analysis (Idler \& Beyamini, 1997). It has also been found to have an influence on the use of healthcare services and the monitoring of patient 
response to physicians' advice (Aday \& Andersen, 1981).

According to the WHO definition, physical activity is associated to health and health-impacting lifestyles such as alcohol consumption, tobacco use, diet and nutrition and others. Regular physical activity has been shown to have clear benefits for health (USDH, 2008; Corbin, Pangrazi, \& Welk, 1994). Some authors and institutions hold that both adults and the elderly can gain additional health benefits through physical activity (ACSM, 2009) when the activity is increased in intensity, frequency and/or duration. In the specific case of the elderly, regular physical activity increases average life expectancy through its influence on chronic disease development, through the mitigation of age-related biological changes and their associated effects on health and well-being, and through the presservation of functional capacity (ACSM, 2009).

Spain ranks first among Europe countries in terms of physical inactivity per inhabitant, although interest in sport for exercise, leisure and entertainment is on the rise. Moreover, the elderly in Spain participate less in sports activities and/or physical exercise programmes than the rest of the population (Armstrong \& Morgan, 1998; Dalloso, Morgan, Bassey et al., 1998). In a study on sports habits in Spain conducted in the year 2000 (García-Ferrando, 2001), individuals aged 65 - 74 were included in the study population and the sample, empirically demonstrating that 8 per cent of this age group participated in physical and sports activities (with the exception of walking). In the most recent survey on sport-related habits conducted in Spain (CSD-CIS, 2005), only 17 per cent of respondents above the age of 65 stated that they practised sports compared to 58 per cent of young people aged 15 - 24. In that study, García Ferrando (García-Ferrando, 2006) points to increased participation in sport among people over the age of 55 and believes that this increase is a significant change that merits further study in a future survey. Similar participation rates were observed in a recent Rand D\&I study conducted in Spain on physical activity among the elderly by Martínez (Martínez, González, Jiménez-Beatty et al., 2009) using a representative sample of the Spanish population. Martínez found that 19.6 per cent of women and 14.8 per cent of men engage in one or more physical or sports activities per week, while 92.2 per cent of men and 81.9 per cent of women state that they go for walks once or more a week.

The above data justify the objective of this article: to examine if participating in sport and physical activity influences perceived health among the elderly and determine which activities contribute to better perceived health among them. To achieve these aims, we have studied the elderly in Spain given that, as mentioned above, the country is undergoing a marked process of population ageing accompanied by a high rate of sendentariness.

\section{Material and Methods}

In order to perform the research, data was drawn from the study titled "Deporte, Salud and Calidad de Vida" (Sport, Health and Quality of Life, E-0727) conducted by the Institute for Advanced Social Studies of the Spanish National Council for Scientific Research (IESA-CSIC) through an agreement for collaboration with the Obra Social la Caixa. A total of 2018 computer-assisted telephone (fixed and mobile) interviews (CATI) were conducted using a structured questionnaire. The questionnaire was administered to Spanish respondents aged 16 - 79 years old. The sample size was calculated in order to gather information that was representative of different age groups, with particular attention given to a subsample comprised of respondents aged 65 - 79 years old (804 interviews). Sampling was stratified, with gender and age used as control variables for the entire sample selected via mobile phones. In addition to these two variables, the variables "province" and "size of habitat" were used for the sample selected via fixed lines. The distribution of the sample that was selected via fixed or mobile phones was estimated by minimising the sample variance. Finally, the assumed error level was \pm 3.5 per cent for the group of respondents aged 65 - 79 years old. The data were treated using SPSS 12.0 and 15.0 statistical software.

The research methodology comprised a bivariate analysis of the individual's perceived health and physical activity, which was measured according to three variables: walking or strolling, participation in sport, and daily physical activity. Variable association analysis was performed using Pearson's chi-square test, which is presented alongside the analysis of typified residuals for each category.

A dependency analysis (categorical regression) was then performed with perceived health among the elderly as the dependent variable and sociodemographic characteristics, physical activity and sport as independent variables. The co-influence of certain variables on others also affecting perceived health status has shown that this method of analysis is appropriate as it accounts for the effect of each indicator on the dependent variable, while the effects of the other variables remain ceteris paribus. In this study, we have measured physical activity and sport among the elderly by means of three indicators:

- Sport, which is measured as a function frequency and intensity,

- Walking or strolling, which denotes if the individual takes brisk walks or strolls, their frequency and intensity (amount of time dedicated to the activity), and

- Daily activities, which are measured by means of categories that best describe the individual's situation regardless of the main activity they engage in (work, household tasks, etc.) while either remaining seated most of the day, standing but not walking large distances or walking frequently.

Although walking and strolling or daily activities do not involve as great an expenditure of energy as sport-related activity, they do require physical exertion, which is very important at this age. Due to the fact that health status in this age group is closely associated to these particular activities, in this study we consider walking, strolling or daily activities to be physical activities. These three indicators will serve to determine to what degree the elderly in Spain engage in an active lifestyle and the influence these activities have on perceived health status. The dependent variable "perceived health" was measured by means of a 5-category Likert scale: "very good", "good", "neither good nor poor", "poor" and "very poor".

Given that the dependent variable and the independent variables are not metric, but ordinal or nominal, is it not advisable to perform classic regressions. For this reason, a categorical regression analysis with optimal scaling was performed. In general, this method functions in a similar way to classical linear regression with the exception that the variables are transformed by optimal scaling.

\section{Results}

On the whole, the elderly in Spain believe that their health is 
good or very good (49.9 per cent), while 30 per cent state that their health is neither good nor poor and only 10.9 per cent describe their health as being poor or very poor (see Table 1).

The large proportion of individuals of this age who perceive their health in positive terms should come as no surprise. Similar studies (Atchley, 1999) have pointed to the accommodation regarding what is commonly accepted as being "normal" or "optimum" health at this stage of life. Indeed, when faced with the same health problem, the elderly perceive themselves to be healthier than younger individuals.

When asked the question "Do you think that your health is better, worse or the same as other people of your same age and sex?", the respondents generally state that it is the same (26.9 per cent) or better (22.1 per cent), whereas only 7.6 per cent think that their health is worse than their counterparts. Nonetheless, the modal category "I don't know" is the option chosen by 35.8 per cent of elderly respondents. Furthermore, among individuals who perceive themselves to have worse health than individuals of the same age and sex, the majority believe that their health is "poor" or "very poor", thus indicating that the responses are consistent.

When comparing current health status to the previous year, the elderly do not perceive their health in such a positive manner: 26.3 per cent believe that their health is worse or the same (62.5 per cent), while only 11.1 per cent think that it is better than one year ago. As in the previous case, the responses are much more negative among those who perceive their health to be "poor" or "very poor".

It is also interesting to note that 68.7 per cent of the elderly who were interviewed state that they suffer from pain or feel discomfort in some part of their body. Accordingly, suffering from pain is one of the variables that most influences perceived health, with those who state they suffer pain also citing worse perceived health.

In general, the elderly in Spain were found to be quite sedentary. 35.4 per cent never walk, 6.8 per cent walk only occasionally, 6.5 per cent walk two or three times per week and half of those interviewed state that they walk everyday. A much lower proportion of elderly practise sports: 16 per cent practise sports either everyday or two or three days a week, while 81.4 per cent practise no sports at all. Finally, when the respondents were asked about the activities they engage in on a daily basis (household tasks, leisure, etc.) 30 per cent state that they sit most of the day, 36.3 per cent state that they spend most of the day standing, while 29.9 per cent frequently walk.

As regards respondents' assessment of sport and physical activity, it is important to highlight that 95.1 per cent of the elderly in Spain believe that these activities are "good for your health", while 90.2 per cent think that they "make you feel bet

Table 1.

Responses obtained per item on perceived health.

\begin{tabular}{lccc}
\hline $\begin{array}{c}\text { QUESTIONS } \\
\text { P1_6-As regards your health, } \\
\text { do you feel that it is...? }\end{array}$ & $\begin{array}{c}\text { \% Response } \\
\text { (total sample) }\end{array}$ & $\begin{array}{c}\text { \% Response } \\
\text { (elderly sample) }\end{array}$ & Dif \\
\hline 1) Very poor & $2.5 \%$ & $6.6 \%$ & $4.1 \%$ \\
2) Poor & $6.2 \%$ & $13.0 \%$ & $6.8 \%$ \\
3) Neither good nor poor & $20.5 \%$ & $30.0 \%$ & $9.5 \%$ \\
4) Good & $44.8 \%$ & $36.1 \%$ & $8.7 \%$ \\
5) Very good & $25.9 \%$ & $13.8 \%$ & $12.1 \%$ \\
\hline
\end{tabular}

Note: Study E0727 IESA-CSIC. Base: percentage of cases. ter about yourself', that is, the majority believe that sport and physical activity are beneficial to one's overall well-being. In contrast, less than 10 per cent of the respondents think that sport and physical activity is "bad for your heart", "worsens your general state of health", or is "bad for your bones". However, a significant number of elderly individuals state that these activities "cause anxiety" (26 per cent).

The relationship between overall health and an active lifestyle is examined in this paper through the association between the indicator "perceived health" and activities that involve some type of physical exertion. Table 2 shows the values of each variable in relation to health status, indicating whether or not the differences are statistically significant and the value of the typified residuals for each category of responses.

As can be seen in Table 2, walking or strolling have a positive effect on the subjective perception of health status among the elderly, with worse health being observed among those who never walk. As the typified residuals (see also Figure 1) demonstrate, the categories that are most closely associated to health are "don't walk" and "walk everyday". These are the two categories in which they elderly most frequently classify themselves, with only a small proportion indicating that they walk only occasionally or several days a week. The same thing oc-

Table 2.

Perceived health according to physical activity.

\begin{tabular}{|c|c|c|c|c|}
\hline \multirow[b]{2}{*}{$\begin{array}{l}\text { WALK OR STROLL } \\
\left({ }^{* *}\right)\end{array}$} & \multicolumn{4}{|c|}{ Perceived health } \\
\hline & $\begin{array}{l}\text { Poor or very } \\
\text { poor }\end{array}$ & Fair & $\begin{array}{l}\text { Good or } \\
\text { very good }\end{array}$ & Total \\
\hline Don't walk & $\begin{array}{l}51.3 \% \\
(3.20)\end{array}$ & $\begin{array}{l}42.5 \% \\
(1.72)\end{array}$ & $\begin{array}{l}25.9 \% \\
(-3.32)\end{array}$ & $35.9 \%$ \\
\hline Walk occasionally & $\begin{array}{c}5.2 \% \\
(-0.66)\end{array}$ & $\begin{array}{c}5.0 \% \\
(-0.95)\end{array}$ & $\begin{array}{l}8.0 \% \\
(1.15)\end{array}$ & $6.6 \%$ \\
\hline $\begin{array}{l}\text { Walk } 2 \text { or } 3 \\
\text { times a week }\end{array}$ & $\begin{array}{c}4.5 \% \\
(-0.98)\end{array}$ & $\begin{array}{l}6.7 \% \\
(0.06)\end{array}$ & $\begin{array}{l}7.3 \% \\
(0.56)\end{array}$ & $6.6 \%$ \\
\hline Walk everyday & $\begin{array}{l}39.0 \% \\
(-2.09)\end{array}$ & $\begin{array}{l}45.8 \% \\
(-1.12)\end{array}$ & $\begin{array}{l}58.8 \% \\
(2.17)\end{array}$ & $51.0 \%$ \\
\hline $\operatorname{SPORT}\left(^{* *}\right)$ & $\begin{array}{l}\text { Poor or } \\
\text { very poor }\end{array}$ & Fair & $\begin{array}{l}\text { Good or } \\
\text { very good }\end{array}$ & Total \\
\hline Don't do sports & $\begin{array}{l}91.1 \% \\
(1.34)\end{array}$ & $\begin{array}{l}82.6 \% \\
(0.19)\end{array}$ & $\begin{array}{l}77.0 \% \\
(-0.99)\end{array}$ & $81.5 \%$ \\
\hline $\begin{array}{l}\text { Do sports } \\
\text { occasionally }\end{array}$ & $\begin{array}{c}1.9 \% \\
(-0.38)\end{array}$ & $\begin{array}{c}1.7 \% \\
(-0.73)\end{array}$ & $\begin{array}{l}3.0 \% \\
(0.80)\end{array}$ & $2.4 \%$ \\
\hline $\begin{array}{l}\text { Do sports } 2 \text { or } 3 \\
\text { times a week }\end{array}$ & $\begin{array}{l}3.2 \% \\
(-2.71)\end{array}$ & $\begin{array}{l}11.2 \% \\
(0.58)\end{array}$ & $\begin{array}{l}12.0 \% \\
(1.25)\end{array}$ & $10.0 \%$ \\
\hline Do sports everyday & $\begin{array}{c}3.8 \% \\
(-1.17)\end{array}$ & $\begin{array}{c}4.6 \% \\
(-0.99)\end{array}$ & $\begin{array}{l}8.0 \% \\
(1.50)\end{array}$ & $6.1 \%$ \\
\hline $\operatorname{ACTIVITY}\left({ }^{* *}\right)$ & $\begin{array}{l}\text { Poor or very } \\
\text { poor }\end{array}$ & Fair & $\begin{array}{l}\text { Good or } \\
\text { very good }\end{array}$ & Total \\
\hline Sit & $\begin{array}{l}48.7 \% \\
(4.02)\end{array}$ & $\begin{array}{l}36.6 \% \\
(1.58)\end{array}$ & $\begin{array}{l}19.9 \% \\
(-3.83)\end{array}$ & $30.9 \%$ \\
\hline Stand & $\begin{array}{l}31.4 \% \\
(-1.34)\end{array}$ & $\begin{array}{l}36.6 \% \\
(-0.35)\end{array}$ & $\begin{array}{l}41.6 \% \\
(1.14)\end{array}$ & $38.0 \%$ \\
\hline Walk & $\begin{array}{c}19.9 \% \\
(-2.52)\end{array}$ & $\begin{array}{l}26.8 \% \\
(-1.18)\end{array}$ & $\begin{array}{l}38.5 \% \\
(2.56)\end{array}$ & $31.1 \%$ \\
\hline
\end{tabular}

Note: Study E0727 IESA-CSIC. $\left(^{* *}\right)$ indicates that the differences in subjective health are statistically significant in this sample with $p<0.01$. The information that appears in the parenthesis below the percentages indicates the value of the typified residuals for each value. 


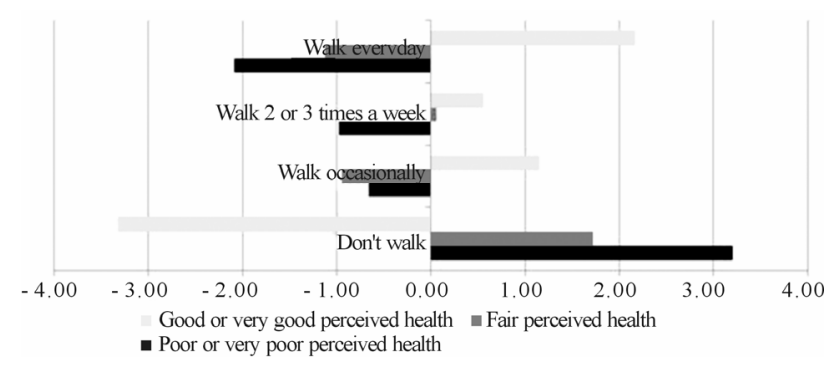

Figure 1.

Typified residuals: Perceived health according to frequency and intensity of walking or strolling. Source: Study E0727 IESA-CSIC.

curs among those who practise or do not practise sports: the main differences are found between those who practise no sports at all ( 80 per cent of the elderly) and the rest of the respondents and those who practise no sports at all have poorer perceived health. However, the greatest differences are observed in the group that practises sports several times a week as they have a positive opinion about their health. Finally, sitting most of the day is related to poorer health status as compared to walking or standing, although the most significant differences in terms of perceived health status are found in the group that spends most of the day sitting (see Figure 2).

As the bivariate analysis has shown, participating in some type of physical activity or sport is beneficial for health and the elderly who engage in such activities perceive their health in a more positive manner than those who do not engage in them. Nonetheless, as mentioned above, we have performed a regression analysis with all of the variables to obtain more solid conclusions (see Table 3).

More than 80 per cent of the elderly respondents state that they do not engage in any type of sport-related activity, while 50 per cent walk or stroll everyday. Thus, although practising sports is statistically significant with regard to how the elderly perceive their health, sport is of little importance in relative terms in comparison to the rest of the variables included in the model. Among the variables associated with physical activity, the most important ones in terms of perceived health in this age group are daily activities followed by walking or strolling. Indeed, the elderly point to the importance of not spending the day sitting as it is easy to do so given that they have so many free hours to occupy.

As regards the sociodemographic variables that influence health status, gender is found to be the most important. This variable explains 37.7 per cent of the total variability $\left(R^{2}\right)$ and shows that women have poorer health than men. Income level and educational level are also found to have an effect on perceived health among the elderly. Both variables have a positive sign, that is, the higher the income or educational level, the better perceived health. Although the rest of the variables are significant, they account for less than 4 per cent of the total variability.

\section{Discussion}

In contrast to physical inactivity (sendentariness), which is a major health risk factor, physical activity is beneficial from a physiological, psychological and social standpoint as self-reported changes in health have shown.

Sport-related activities are not as widespread among the elderly of Spain as they are among other groups, with only 16.2

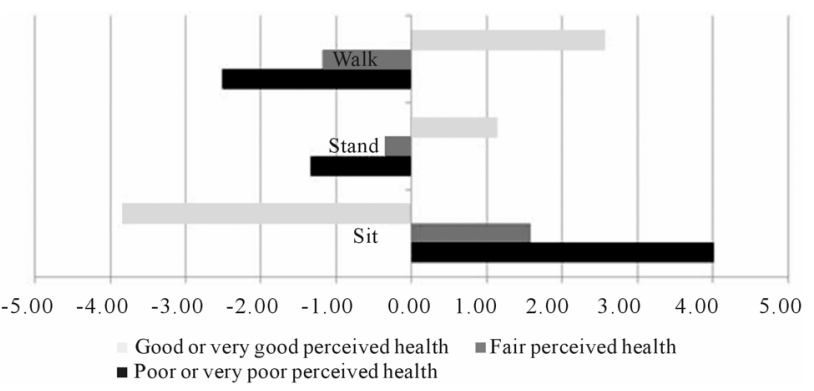

Figure 2.

Typified residuals: Perceived health according to daily activities. Source: Study E0727 IESA-CSIC.

Table 3.

Regression analysis. Dependent variable (DV): Perceived health. Independent variables (IV): Physical activities and sociodemographic variables.

\begin{tabular}{ccc}
\hline & \multicolumn{2}{c}{ DV: Perceived health } \\
\hline B $(\mathrm{SE})$ & $\mathrm{Imp}$ \\
Walk or stroll & $0.148(0.038)^{* *}$ & $15.5 \%$ \\
Sport & $0.078(0.037)^{*}$ & $2.7 \%$ \\
Activity & $0.159(0.038)^{* *}$ & $16.3 \%$ \\
Sex & $-0.276(0.044)^{* *}$ & $37.7 \%$ \\
Marital status & $0.070(0.037)^{*}$ & $3.8 \%$ \\
Education level & $0.112(0.038)^{* *}$ & $9.6 \%$ \\
Employment status & $-0.079(0.042)^{*}$ & $3.4 \%$ \\
No. household members & $0.152(0.055)^{* *}$ & $3.1 \%$ \\
Living situation & $-0.202(0.056)^{* *}$ & $2.9 \%$ \\
Income & $0.097(0.042)^{*}$ & $11.7 \%$ \\
Corrected $\mathrm{R}^{2}$ & $17.2 \%$ & \\
\hline
\end{tabular}

Note: The following values are given for each variable: Beta coefficients (B), standard error (SE) and statistical significance. Statistical significance is denoted as follows: ${ }^{* *}$ significant at $99 \%(p<0.001)$; ${ }^{*}$ significant at $95 \%(p<0.05)$. The "Imp" column refers to Pratt's Importance; a measure that indicates which variable has the strongest influence on the dependent variable. This statistic is calculated by multiplying the regression coefficient of each variable by the correlation with the dependent variable and dividing the result by the $\mathrm{R}^{2}$ of the model. The sum of the importance of all the variables is 100 . Finally, the $\mathrm{R}^{2}$ of the model is given, that is, the percentage of explained variance (variability due to the variables used in the regression). Source: Study E0727 IESA-CSIC.

per cent stating that they engage in activities of this type on a regular basis (several days a week or everyday). In contrast, however, walking or strolling is a very popular physical activity among a large proportion of elderly individuals (over 60 per cent), with the majority engaging in this activity everyday (50.5 per cent). Nonetheless, the elderly in Spain lead a very sedentary lifestyle, with watching television being one of the main activities they engage in during their free time (as this survey has shown).

According to the results of this study, practising sports has a statistically significant effect on perceived health among people in the $65-79$ years old age group. However, the importance of practising sports on the variability of self-perceived health is 
negligible, with differences chiefly found between those who practise sports and those who do not, while frequency does not appear to have an influence on perceived health. This contrasts with the American College of Sports Medicine which, basing their findings on a continual cycle of activity-inactivity, postulates that "more is better"; a factor that has proven to have no effect in our study among the elderly.

The same does not hold for walking or strolling. These activities were found to be significant and have a greater influence on perceived health than sport. Moderate physical activity produces greater satisfaction with health among this age group and is also easier to do (many more elderly individuals do moderate physical activity). Indeed, it is common to see elderly people walking alone or in groups in both rural and urban areas for leisure purposes, health reasons or following physicians' advice.

The activities that the elderly engage in on a daily basis (walking, standing and walking short distances or sitting most of the day) also have an influence on the way they perceive their health. The elderly, who typically lead a more sedentary lifestyle than the general population, attach greater importance to keeping active and not remaining idle as a means to achieving better health.

In general, women show worse perceived health status than men with statistically significant differences. Moreover, this variable has the greatest importance in terms of perceived health among the elderly (accounting for 37.7 per cent of the explained variance- $-\mathrm{R}^{2}$ ). These results are in line with conclusions reached in other studies (Gonzalo \& Pasarín, 2004; Hoffmeister \& Vallebuena, 2006). In addition, women have generally been found to do the least amount of physical activity in this and other research studies (Martínez, 2005). Engaging in less physical activity could have a negative effect on perceived health, while a negative view of one's health could, in turn, result in low participation in physical activity, thus leading to a vicious cycle as Johnson and Wolinsky (Johnson \& Wolinsky, 1993) have reported.

Income level is also found to affect perceived health status as those who have higher incomes state that they are more satisfied with their health. The association between higher economic levels and better health has already been studied and demonstrated empirically in research on health inequalities (Raphael, 2006), and in studies on differences in physical activity due to cultural and economic determinants (Moscoso \& Moyano, 2009). Finally, it should be noted that elderly individuals with higher educational levels cite better health; a finding that has also been reported in studies on health inequalities due to socioeconomic factors (Fernández, Clúa, Báez, Ramírez, \& Prieto, 2000; Gonzalo \& Pasarín, 2004; Gallegos-Carrillo \& GarcíaPeña, 2006). The elderly women in our study (and in others cited here) have lower educational and income levels than the men, while a greater proportion are widows or live alone; factors that may also lead to poorer health.

Increased life expectancy and the decline in fertility in Spain and other western countries are factors that have contributed to rapid population ageing. The proportion of the population over the age of 65 is on the rise, making this group the focus of growing public concern. Due to the physiological deterioration that accompanies this stage of life, many public policies are oriented towards healthcare initiatives and measures to promote healthy lifestyles among the elderly. Moreover, an ageing population is more sedentary, thus affecting the physical and mental processes of ageing. For this reason, health organisations recommend that the elderly engage in physical activity and/or participate in sports activities to promote a broader concept of health. Indeed, many of the messages directed at this age group centre on the benefits of moderate activity such as walking, swimming, cycling or others.

As we have shown in this paper, self-reported health among the elderly in Spain is influenced by participation in moderate-intensity aerobic physical activity, principally frequent walking and strolling or daily activities. The claim that greater health benefits can be gained through increasing the frequency, intensity and duration of physical activity have not been confirmed for this age group, particularly when health is not measured in the biological sense of the term, but more broadly as physical, mental and social well-being as defined by the World Health Organization.

A great number of sport and healthcare institutions emphasise that for physical exercise to be beneficial to health, it is necessary to be physically active for a given duration, frequency and intensity. However, according to our research, it is more important for the elderly to feel that they are active, particularly during a stage of life in which society has declared them to be legally "inactive". In this sense, our results confirm the WHO approach to promote active ageing, which includes moderate physical activity and greater mobility when carrying out daily activities (walking, climbing stairs, gardening, dancing, swimming, etc.). In this same line, other authors also indicate that "doing some type of physical activity is better than doing nothing at all" (USDH, 2008; Blair, Kohl, Gordon, \& Paffenbarger, 1992) and that moderate exercise, which many more people are able to do, may have important health benefits. Thus, the functional capacity or the independence of elderly individuals (that they feel and perceive themselves as people who are not "dependent") will, in many cases, determine how they perceive their health or whether they define themselves as being healthy or ill (Gonzalo \& Pasarín, 2004). As this paper has shown, engaging in activities that require movement and mobility, be they household tasks, walking or strolling everyday or practising a sport, are essential to their health.

In general, people believe that physical activity is beneficial to health, but their words speak louder than their actions. Moreover, as other studies have shown, poor health is cited as one of the main reasons for not participating in physical activity or sport. Although the message is loud and clear, it does not mean that the elderly act accordingly. In fact, many are reluctant to change their lifestyle patterns. This contradiction between "thought and action" has been reported by other authors (Grant, 2001) who explain such behaviour as a result of the lack of socialisation into physical activity during childhood, which has long-lasting effects over time; external barriers to participation in physical activity or internal barriers such as one's own perception of health condition the type and intensity of exercise that elderly individuals believe they can or cannot do. According to Grant, being aware of the benefits to be gained from exercise is not sufficient to motivate the elderly to engage in physical activity, but exercise must be valued in its own right. In our opinion, this approach constitutes an enormous change in how exercise is perceived and would require a greater effort by public institutions to effectively promote active lifestyles among the elderly. However, a less demanding message that focuses on the importance of doing moderate exercise such as walking or strolling does seem to have reached this age group. 
Perhaps this is the example to follow, especially if we assume that increased levels of activity among those aged 65 and over are associated not only to extended life spans, but also greater independence in later life (Bath \& Morgan, 1998). As we have shown, moderate exercise such as walking, or feeling that one is "active", are the driving force of health among older people.

\section{REFERENCES}

ACSM (2009). Exercise and physical activity for older adults. Medicine and Science in Sports and Exercise, 41, 1510-1530. doi:10.1249/MSS.0b013e3181a0c95c

Aday, L. A., \& Andersen, R. (1981). Equity of access to medial care: A conceptual and empirical overview. Medical Care, 19, 4-27. doi:10.1097/00005650-198112001-00004

Armstrong, G., \& Morgan, K. (1998). Stability and change in levels of habitual physical activity in later life. Age and Ageing, 27, 17-23. doi:10.1093/ageing/27.suppl 3.17

Atchley, R. (1999). Continuity and adaptation in aging: Creating positive experiences. Baltimore: The John Hopkins University Press.

Barrios, R., Borges, R., \& Cardoso, L. (2003). Benefits perceived by major adults who exercise [Beneficios percibidos por adultos mayores incorporados al ejercicio]. Revista Cubana de Medicina General Integral, 19.

http://scielo.sld.cu/scielo.php?script=sci_arttext\&pid=S0864-212520 03000200007

Bath, P., \& Morgan, K. (1998). Customary physical activity and physical health outcomes in later life. Age and Ageing, 27, 29-34. doi:10.1093/ageing/27.suppl 3.29

Blair, S., Kohl, H., Gordon, N., \& Paffenbarger, R. (1992). How much physical activity is good for health? Annual Review of Public Health, 13, 99-126. doi:10.1146/annurev.pu.13.050192.000531

CIS-CSD (2005). Sport habits in Spain III. Study no. 2599. Madrid: Center for Sociological Research.

Corbin, C., Pangrazi, R., \& Welk, G. (1994). Towards an understanding of appropriate physical activity levels for youth. Physical Activity and Fitness Research Digest, 1, 1-8. doi:10.1136/jech.42.2.121

Dalloso, H. M., Morgan, K., Bassey, E. J., Ebrahim, S. B. J., Fentem, P. H., \& Arie, T. H. D. (1998). Levels of customary physical activity among the old and the very old living at home. Journal of Epidemiology and Community Health, 42, 121-127.

Entrala, A., Iglesias, C., Veigas, P., \& De-Jesús, F. (2003). Diet and physical exercise: Healthy binomial [Dieta y ejercicio físico: Binomio saludable]. Revista Brasileira de Biociências, 1, 3-8.

Fernández, N., Clúa, A. M., Báez, R. M., Ramírez, M., \& Prieto, V. (2000). Lifestyle, subjective well-being and health of elders [Estilos de vida, Bienestar subjetivo y salud de los ancianos]. Revista Cubana de Medicina General Integral, 16, 6-12.

Fernández-Ballesteros, R. (1992). Myths and realities of the oldness and health [Mitos y realidades sobre la vejez y la salud]. Barcelona: Fundación Caja de Madrid. Colección Gerontología y Sociedad.

Gallegos-Carrillo, K., \& García-Peña, C. (2006). Autoperception of the health: an approximation to the elders in Mexico [Autopercepción del estado de salud: una aproximación a los ancianos en México]. Revista de Saúde Pública, 40, 792-801. doi:10.1590/S0034-89102006000600008

García-Ferrando, M. (2001). The Spanish and the sport: Practices and behaviors in the last decade of the 20th century [Los españoles y el deporte: prácticas y comportamientos en la última década del siglo $X X]$. Madrid: MECD-CSD.
García-Ferrando, M. (2006). Postmodernism and sport: Between the individualization and the extension. Survey of Spanish sports habits 2005 [Posmodernidad y Deporte: Entre la individualización y la masificación. Encuesta sobre hábitos deportivos de los españoles 2005]. Madrid: CSD-CIS.

Gonzalo, E., \& Pasarín, M. I. (2004). La salud de las personas mayores. Gaceta Sanitaria, 18, 69-80. doi:10.1157/13062253

Grant, B. (2001). You're never too old: Beliefs about physical activity and playing sport in later life. Ageing and Society, 21, 777-798. doi:10.1017/S0144686X01008492

Hoffmeister, L., \& Vallebuena, C. (2006). Difference in the State of health Perceived according to labor situation [Diferencias en el Estado de Salud Percibido según situación laboral]. Chile: Gobierno de Chile.

Idler, E. L., \& Benyamini, A. (1997). Self-rated health and mortality: A review of twenty-seven community studies. Journal of Health and Social Behavior, 38, 21-37. doi:10.2307/2955359

Johnson, R. J., \& Wolinsky, F. D. (1993). The structure of health status among older adults: Disease, disability functional limitation and perceived health. Journal of Health and Social Behavior, 34, 105-121. doi: $10.2307 / 2137238$

Martínez, J. (2005). Study of the physical activity and sports of the women of the municipality of Madrid: habits, demands and barriers [Estudio sobre la actividad física y deportiva de las mujeres del municipio de Madrid: hábitos, demandas y barreras]. Área de Gobierno de Empleo y Servicios a la Ciudadanía. Madrid: Ayuntamiento de Madrid.

Martínez, J., González, M. D., Jiménez-Beatty, J. E., Graupera, J. L., Martín, M., Campos, A., \& Del-Hierro, D. (2009). The habits of physical activity of the major women in Spain [Los hábitos de actividad física de las mujeres mayores en España]. International Journal of Sport Science, 5, 81-93.

Moscoso, D., \& Moyano, E. (2009) Sport, health and quality of life. Barcelona: The "la Caixa" Foundation.

Raphael, D. (2006). Social determinants of health: Present status, unanswered questions, and futures directions. International Journal of Health Services, 36, 651-67. doi:10.2190/3MW4-1EK3-DGRQ-2CRF

Testa, M. A., \& Simonson, D. C. (1996). Assessment of quality-of-life outcomes. The New England Journal of Medicine, 334, 835-840. doi:10.1056/NEJM199603283341306

United States Department of Health and Human Services (2008). Physical activity guidelines advisory committee report. Atlanta, GA: Departament of Health and Human Services, Centers for Disease Control and Prevention, National Center for Disease Chronic Disease Prevention and Health Promotion. http://www.health.gov/paguidelines/

Ware, J. E. (1987). Standards for validating health measures: Definition and content. Journal of Chronic Diseases, 40, 473-480. doi:10.1016/0021-9681(87)90003-8

Weineck, J. (2001). Health, exercise and sport [Salud, ejercicio y deporte]. Barcelona: Paidotribo.

World Health Organization (WHO) (1952). Constitution of the World Health Organization. Handbook of basic documents (5th ed., pp. 3-20). Ginebra: Pelais des Nations.

World Health Organization (WHO) (2005). World day of the health. For your health, move [Día Mundial de la Salud. Por tu salud, imuévetei].

http://www.who.int/docstone/world-health-day/2002/lecturas.es.shtm 1 